\title{
NEWSLETTER 2014
}

\author{
CATHOLIC RECORD SOCIETY CONFERENCE 2014
}

\author{
by HANNAH THOMAS
}

The 57th Annual Conference of the Catholic Record Society was held at Downing College, Cambridge, 28-30 July 2014. For the first time in its history, the Society sent out a call for papers to the wider academic community for full papers, short communications or works in progress, which resulted in many new academics attending who had not previously been to the CRS conference. Set in the beautiful surroundings of Downing College and aided by their helpful and accommodating staff, the conference featured several panels over three days, ending with our traditional excursion to a place of recusant interest.

The first panel focused on the role of female religious from early modern and modern perspectives. The first paper was from Dr Victoria Van Hyning, who as the recipient of a Williams award in 2013, presented the outcome of her research on Augustinian convent biography. Dr Van Hyning presented a variety of fascinating case studies of seventeenthcentury Augustinian biographies, predominantly composed at the request of superiors to further a nun's own spiritual development, or to assist other sisters on their own spiritual journeys. Dr Van Hyning presented a variety of fascinating case studies of seventeenth-century Augustinian autobiographies that go beyond the vida por mandato genre, which were typically composed at the request of superiors and confessors. Van Hyning presented a persuasive argument that texts, such as anonymous chronicles, which are not obviously autobiographical, could provide nuns with an opportunity for self-expression. Van Hyning also discussed the conversion narrative of the nun Catherine Holland of Nazareth, whose first person text provides a rather different example of the autobiographical genres available to nuns.

The second paper of the panel was a short communication from Dr Carmen Mangion, who has recently begun a project on female religious life post-1940. Dr Mangion outlined the scope and focus of her project, which will look at international perspectives of female religious life during and after Vatican II. The project has just been granted a Williams award for 2014, and will, when finished, hopefully be the subject of a full paper at a future CRS conference.

After a short coffee break, the first afternoon's papers concluded with a fascinating overview of the newly repurposed Ushaw College collections, which are currently being catalogued and evaluated. Dr Jonathan 
Bush and Claire Marsland presented a detailed look at the archive and object collections in particular, highlighting the enormous range of material that survives at Ushaw - a particular favourite of the delegates was a photograph of ice-skating seminarians! The collection has huge research potential across many areas and disciplines and will be essential to many future projects.

Monday evening saw a first for the Catholic Record Society - a book launch. It was apt for the Society to host the official launch of Dr Alana Harris's recent publication Faith in the Family: A Lived Religious History of English Catholicism, 1945-1982 (Manchester University Press) - Dr Harris presented her first academic paper as a $\mathrm{PhD}$ student at the 2005 conference, and came back last year to present one particular aspect of the book's findings. The launch included an amusing musical interlude with Tom Lehrer's The Vatican Rag entertaining the delegates, and was supported by Manchester University Press.

The second day of the conference began with a paper from Dr Susan Royal, examining Catholic perceptions of Lollardy. Dr Royal noted that early evangelicals had been faced with the task of disentangling themselves from their predecessors' associations with treason and rebellion. She outlined several interesting case studies, including one cleric who participated in the burning of his own books!

The second paper of the day was a biographical study of the life and career of Cardinal Francis Bourne, presented by Fr Mark Vickers of the Diocese of Westminster. Bourne, created Cardinal in 1911, is the subject of Fr Mark's recent biography entitled By the Thames Divided (Gracewing, 2013). Fr Mark drew attention to the many historical controversies surrounding Bourne, and hopes that his new biography will restore him to his rightful place in British Catholic history.

The rest of the afternoon was a panel focused on private and public writing. The first paper in the panel was given by Clarinda Calma, Jolanta Rzegocka and Teresa Bela, who presented a fascinating study of two distinct Polish editions of Campion's Rationes Decem, both printed within a few years of the original. The Polish editions were not just a scholarly linguistic exercise, but each played a vital role in confessional debates within Poland.

The next paper in the panel was from Dr Serenhedd James, who presented an overview of the letters of George Errington, a nineteenthcentury churchman, which form part of Dr James's forthcoming biography on Errington. James also made some interesting points about preserving original order when digitising archives, as this had led him to some unexpected discoveries.

After a short break, Dr Emilie Murphy presented her research into the soundscapes of early modern Catholicism, using the Catholicism and networks of the Blundell family as a case study. Dr Murphy drew attention to the ease with which appropriately Catholic messages could be 
spread by repurposing existing ballad tunes, which could also recall preReformation traditions. The paper was accompanied by several excellent musical examples, and served to highlight the importance of this understudied element of post-Reformation religious life.

The final two papers of the day presented a snapshot of two ongoing research projects. The first was from Katie McKeogh, a PhD candidate at the University of Oxford. McKeogh presented her ongoing research into the Brudenell manuscript in the Bodleian Library, postulating that it was probably composed by someone close to Tresham, such as a servant or a relative, rather than by Tresham himself.

We then heard from Ruth Barbour, a PhD candidate at the University of Warwick. Barbour presented her research into the fascinating character of John Whittingham, an eighteenth century Catholic who had a hugely successful career as a nurseryman and importer of plants. Barbour's examples suggested that his faith allowed him to trade with a large international community, and in some cases, made his work easier. Both papers were well received, and it is hoped both speakers will return to present the conclusion of their researches at a future conference.

The final session took place on the third day of the conference. First was Martin Dodwell, who outlined his recent research and new discoveries of the life and career of Anne Line, as well as his research into her presence among Shakespeare's more cryptic works. Dodwell particularly drew attention to coded references to Line in The Phoenix and the Turtle, revealing that she was known by several different names and had also had a son with her husband Roger Line, before their separation at his exile. A lively discussion followed before we moved on to our penultimate paper, presented by Giada Pizzoni, a PhD student at the University of St Andrews. Pizzoni, who was the recipient of a Rogers award in 2012, presented her fascinating research into the economic strategies employed by the Catholic community in the long eighteenth century, particularly focusing on the successful investments of Bishop Richard Challoner.

The final paper of the conference was a study of Our Lady Vulnerata and her connections with the English College at Valladolid. The paper was read by the conference director on behalf of Fr Peter Harris, who was unable to be with us in person.

The conference ended with our traditional excursion to a place of recusant interest. This year, delegates were led by Dr Francis Young to Ely Cathedral and the Bishop's Palace, which had been the prison for notable Catholics such as Thomas Tresham and John Feckenham. Dr Young led us on a very informative and interesting tour, pointing out many interesting architectural features that had only been uncovered during recent renovations. Delegates were able to explore the beautiful surroundings of the main cathedral as well, before returning to Downing.

A total of 61 delegates attended the conference, many for the first time. Delegates who were unable to be with us in person can now follow 
proceedings on Twitter, from the Society@CatholicRS and by searching for \#crs2014. Several summaries have been posted by delegates on their own blogs or web pages, such as Dr Francis Young (http://eacatholichistory. blogspot.co.uk/2014/07/crs-2014-day-2.html), Liesbeth Corens (https:// storify.com/onslies/catholic-records-society-2014) and Hannah Thomas (cwmjesuitlibrary.blogspot.com). The conference director would like to personally thank all speakers, chairs, tweeters and delegates for their contributions to a very successful and thoroughly enjoyable conference. The 58th annual conference will take place at Downing College, Cambridge, 20-22 July 2015. 